\title{
Free Estriol Measurement
}

National Cancer Institute

\section{Source}

National Cancer Institute. Free Estrio/ Measurement. NCI Thesaurus. Code C81963.

The determination of the amount of free estriol present in a sample. 